\title{
ANALISIS PERBANDINGAN TEKNIK PENERJEMAHAN ISTILAH TABU DALAM FILM THE WOLF OF WALL STREET DAN DUA TERJEMAHANNYA (SUBTITLE RESMI VCD DAN AMATIR DARI SITUS SUBSCENE.COM) SERTA DAMPAKNYA PADA KUALITAS TERJEMAHAN
}

\author{
Nurul Intan Sari, M.R. Nababan, Djatmika \\ Magister Linguistik Pascasarjana Universitas Sebelas Maret \\ intan@disolo.com
}

\begin{abstract}
Nurul Intan Sari. S131408006. 2016. A Comparison Analysis of Translation Techniques of Taboo Words in The Wolf of Wall Street and the Two Subtitle Versions (VCD and Amatuer Subtitles from subscene.com) and Its Impact toward the Translation Quality. Supervisors: (1) Prof. Drs. M.R. Nababan, M.Ed., M.A., Ph.D. (2) Prof. Dr. Djatmika, M.A. Thesis. Postgraduate Program in Lingustics Majoring in Translation Studies. Sebelas Maret Untiversity. Surakarta.
\end{abstract}

This research is conducted by analyzing taboo words in The Wolf of Wall Street movie and its two subtitle versions. The aims of this research are to describe: (1) form and classification of taboo words found in The Wolf of Wall Street movie, (2) the translation techniques used for translating taboo word in The Wolf of Wall Street movie and its two subtitle version, (3) the translation quality of taboo words translations in VCD and amateur subtitles of The Wolf of Wall Street movie, (4) the impact of translation techniques toward the quality of taboo words translations in VCD and amateur subtitles of The Wolf of Wall Street movie.

The research method applied is descriptive qualitative. In addition to that, it is embedded case study. The sources of data consist of documents and informants selected with purposive sampling technique. The documents are The Wolf of Wall Street movie and its two subtitle versions. Informants are validator and three raters. The data are taboo words that have been validated by validator and the information about translation quality given by raters. The techniques of collecting data are document analysis, questionnaire, and focus group discussion. The data were analyzed by using ethnography method composed by Spradley (1980)

The findings show that there are two kinds of grammatical unit of taboo words, they are word and phrase. Sexual references and offensive slang are the dominant categories found in this research. In VCD version, the translation techniques used are established equivalence, reduction, amplification, literal, borrowing and generalization. Established equivalence creates high level of accuracy and acceptability. Reduction affects the quality with low level of accuracy but can create acceptable translations. Meanwhile, in the amateur version, there are seven translation techniques used. They are established equivalence, reduction, amplification, borrowing, generalization, literal, and compensation. This research finds that established equivalence makes the taboo words translations accurate and acceptable. Reduction and the other techniques results in the low level of accuracy but high level of acceptability. Based on the findings, it can be drawn that the translation techniques applied affect the quality of taboo word translations in term of accuracy and acceptability.

Keywords: taboo words, translation techniques, accuracy, acceptability 


\begin{abstract}
ABSTRAK
Untuk menghasilkan suatu terjemahan istilah tabu yang baik, penting bagi penerjemah untuk mengetahui budaya pembaca sasaran karena setiap budaya mempunyai perbedaan dalam hal penggunaan istilah tabu. Penelitian ini bertujuan mengidentifikasi satuan gramatikal dan jenis istilah tabu, teknik penerjemahan yang digunakan, kualitas terjemahan dalam film The Wolf of Wall Street dan dua terjemahannya, serta menjelaskan dampak penggunaan teknik penerjemahan terhadap kualitas terjemahan istilah tabu.

Peneltian deskriptif dengan desain studi kasus terpancang. Sumber data berupa film The Wolf of Wall Street dan dua terjemahannya, serta informan. Data berupa istilah tabu dan hasil dari diskusi kelompok dengan rater mengenai kualitas terjemahan. Teknik pengumpulan data dengan analisis dokumen, kuesioner dan focus group discussion.

Ditemukan dua bentuk istilah tabu: kata dan frasa. Jenis istilah tabu yang dominan adalah sexual references dan offensive slang. Pada subtitle VCD, ditemukan enam teknik penerjemahan. Sedangkan pada subtitle amatir, terdapat tujuh teknik penerjemahan. Walaupun demikian, ditemukan bahwa pada kedua subtitle tersebut teknik padanan lazim merupakan teknik yang memiliki andil positif dalam menghasilkan tingkat keakuratan dan keberterimaan tinggi pada terjemahan istilah tabu. Sedangkan, reduksi membawa dampak negatif pada kualitas terjemahan dari segi keakuratan dan keberterimaan.

Kata kunci: istilah tabu, teknik penerjemahan, keakuratan, keberterimaan.
\end{abstract}

\title{
I. PENDAHULUAN
}

Bahasa dan budaya merupakan dua hal yang tidak dapat dipisahkan. Di dalam budaya suatu masyarakat, terdapat norma yag mengatur masyarakat dalam berperilaku dan bertutur kata. Terdapat kata, ekspresi atau pun topik yang dilarang untuk diucapkan atau dibahas. Sesuatu yang dilarang tersebut biasa disebut dengan istilah tabu. Secara umum, tabu merupakan ekpresi masyarakat sebagai luapan emosi yang dipercaya bisa member dampak buruk bagi masyarakat. Tabu sendiri dibedakan 2, yaitu tabu perbuatan dan tabu bahasa. Tabu perbuatan mengacu pada tindakan yang dilarang seperti pernikahan sedarah. Sedangkan, tabu bahasa mengacu oada kata-kata yang dilarang untuk diucapkan. Istilah tabu bisa saja menjadi persoalan serius apabila dikaitkan dengan penerjemahan. Apalagi sekarang ini banyak sekali karya lintas budaya yang masuk ke Indonesia, khususnya film. Hal tersebut juga memicu perkembangan 
subtitling di dunia penerjemahan. Pada era globalisasi ini, subtitle amatir mulai banyak bermunculan yang dengan mudah dapat diunduh secara gratis. Akan tetapi yang menjadi persoalan, film-film yang masuk ke Indonesia tidak jarang ditemukan banyak istilah tabu yang harus diterjemahkan secara akurat dan berterima dalam budaya bahasa sasaran (BSa). Peran penerjemah sangat penting untuk membantu menjembatani dua bahasa yang memiliki latar belakang yang berbeda.

Dilihat dari segi kualitas terjemahan, tidak jarang ditemukan beberapa bagian subtitle amatir lebih bagus jika dibandingkan dengan terjemahan subtitle resmi dari VCD. Oleh karena itu, penulis memilih untuk melakukan penelitian dengan membandingkan terjemahan istilah tabu yang ada pada subtitle VCD dan amatir. Kesalahan seorang penerjemah dalam menerjemahan istilah tabu akan berakibat sangat fatal karena dapat menyinggung budaya lain. Oleh karena itu, seorang penerjemah dituntut agar dapat mengalihkan pesan dari bahasa sumber ke bahasa sasaran tidak hanya dari segi bahasa tetapi juga harus dapat menyesuaikan dengan budaya bahasa sasaran. Jika istilah tabu memang harus diterjemahkan untuk menjaga keutuhan pesan, penerjemah bisa memperhalusnya menjadi istilah yang lebih umum. Hal itu sebagaimana diungkapkan oleh Alavi Younes Sayed dkk, "these strategies were a)censorship/omission b)substitution c)taboo for taboo d)applying euphemism" (2012). Dalam hal ini, penerjemah diperbolehkan untuk menggunakan euphemism dengan cara memperhalusnya. Selain itu, penting bagi penerjemah untuk mengetahui pembaca sasarannya, khususnya jika terdapat banyak istilah tabu didalamnya, yang tentunya harus memperhatikan budaya pembaca karena setiap budaya mempunyai perbedaan dalam hal penggunaan istilah tabu. Maka, penerjemah harus jeli dan paham kepada budaya siapa teks tersebut diperuntukkan (Nababan, 2003). Nababan juga 
menambahkan bahwa secara tidak langsung dalam kegiatan alih pesan, seorang penerjemah mempunyai multiperan. Disamping sebagai penerjemah, dia juga berperan sebagai pembaca teks bahasa sumber dan penulis serta pembaca teks bahasa sasaran (2003). Selain itu, masalah tersebut dapat diatasi dengan mengunakan pendekatan sosiolinguistik dalam menganalisis hubungan penggunaan istilah tabu dengan masyarakat yang terkait satu sama lain. Jika semua pemahaman tersebut sudah dimiliki penerjemah, pada akhirnya penerjemah dapat menyuguhkan hasil terjemahan yang berkualitas kepada penikmat film asing dalam bentuk subtitle maupun dubbing.

Berawal dari masalah penerjemahkan istilah tabu tersebut, peneliti memfokuskan pada istilah tabu yang terdapat dalam film The Wolf of Wall Street beserta dua versi terjemahannya dalam bentuk subtitle (versi subtitle VCD serta subtitle amatir dari situs subscene.com). Pemilihan film The Wolf of Wall Street dilandasi karena film ini mendapatkan penilaian yang bagus pada resensi beberapa situs internasional, seperti www.commonsense.org dan www.rottentomatoes.com. Dasar lain yang menjadi pertimbangan pemilihan film ini adalah jumlah istilah tabu yang muncul memadai untuk melakukan suatu penelitian. Dengan me-review penelitian yang relevan sebelemnya, Peneliti menemukan gap atau celah penelitian yang belum diteliti sebelumnya. Penelitian sebelumnya dirasa belum dapat menjelaskan secara rinci dampak teknik penerjemahan terhadap kualitas terjemahan pada setiap jenis istilah tabu yang ditemukan. Selain itu, analisis perbandingan penerjemahan istilah tabu dalam dua versi subtitle terjemahan juga belum pernah dijadikan sebagai kajian penelitian.

Pada akhirnya, penelitian ini bertujuan untuk mendeskripsikan: (1) bentuk dan jenis istilah tabu yang ditemukan dalam film The Wolf of Wall Street, (2) teknik penerjemahan yang digunakan untuk menerjemahkan istilah tabu dalam film The Wolf 
of Wall Street dan dua versi terjemahannya, (3) kualitas terjemahan istilah tabu dalam dalam film The Wolf of Wall Street versi subtitle VCD dan subtitle amatir dari situs subscene.com, (4) dampak teknik penerjemahan istilah tabu yang digunakan terhadap kualitas terjemahan dalam film The Wolf of Wall Street versi subtitle VCD dan subtitle amatir. Berdasarkan penelitian yang dikaji, peneliti menentukan teori-teori yang dijadikan acuan seperti teori tentang penerjemahan dan istilah tabu.

\section{Pengertian Penerjemahan}

Secara umum, penerjemahan dapat diartikan sebagai proses pengalihan pesan dari bahasa sumber ke bahasa sasaran. Menurut Larson (1998), penerjemahan didefinisikan sebagai suatu aktivitas pengalihan bahasa sumber ke bahasa sasaran. Sementara itu, Newmark (1988) memberikan pemahaman mengenai pengalihan pesan dalam kegiatan penerjemahan. Dalam kegiatan penerjemahan, seorang penerjemah harus mengetahui maksud penulis dari teks asli (teks BSu).

Kemudian, Nida dan Taber (1982) memaparkan bahwa penerjemahan merupakan kegiatan menghasilkan kembali di dalam bahasa sasaran, pesan yang sedekat-dekatnya dan sewajarnya, sepadan dengan pesan dalam bahasa sumber, pertama menyangkut maknanya dan kedua menyangkut gaya. Nida dan Taber menyebutkan bahwa gaya juga menjadi aspek penting dalam penerjemahan. Yang dimaksud dengan gaya disini adalah gaya bahasa.

Walaupun gaya bahasa menjadi salah satu aspek penting, kesepadanan makna tetap menjadi prioritas yang harus didahulukan dalam kegiatan penerjemahan. Dari beberapa pendapat yang diungkapkan oleh para ahli di atas, dapat disimpulkan bahwa 
penerjemahan adalah suatu proses pengalihan pesan dari bahasa sumber ke dalam bahasa sasaran dengan memperhatikan kesepadanan makna.

\section{Teknik Penerjemahan}

Molina dan Albir (2002) menjelaskan bahwa teknik penerjemahan dapat membantu menemukan dan mendeskripsikan prosedur atau cara yang digunakan oleh seorang penerjemah dalam tataran mikro suatu teks. Berikut ini delapanbelas teknik penerjemahan yang dikemukakan oleh Molina dan Albir (2002): adaptasi, amplifikasi, peminjaman, kalke, kompensasi, deskripsi, kreasi diskursif, padanan lazim, generalisasi, amplifikasi linguistik, kompresi linguistik, literal, modulasi, partikularisasi, reduksi, substitusi, transposisi, variasi,

\section{Kualitas Terjemahan}

Para penerjemah diharapkan dapat memberikan suatu teks terjemahan yang baik untuk kalangan pembaca sasaran. Aspek-aspek yang menjadi prioritas utama bagi para penerjemah dalam menghasilkan terjemahan yang baik adalah keakuratan, keberterimaan dan keterbacaan. Sebagaimana yang telah diungkapkan oleh Nababan dkk (2012) bahwa terjemahan dapat dikatakan baik jika: 1) teks terjemahan akurat dari isinya (pesan yang terkandung dalam terjemahan harus sesuai dengan pesan dalam teks sumber), 2) teks terjemahan diungkapkan sesuai dengan kaidah, norma dan budaya yang berlaku dalam bahasa sasaran, dan 3) teks terjemahan mudah dipahami oleh pembaca sasaran. Akan tetapi, tidak jarang para penerjemah berada dalam suatu situasi yang merngharuskan mereka lebih mengutamakan salah satu dari ketiga aspek tersebut dan mengorbankan aspek yang lainnya. 


\section{Istilah Tabu}

Trudgill (dalam Rosidin, 2010) menjelaskan bahwa tabu diyakini sebagai perilaku yang dilarang secara supranatural atau dipandang sebagai tindakan yang amoral. Perilaku tabu dapat ditunjukkan tidak hanya melaui penggunaan kata-kata kasar, tetapi juga dapat ditunjukkan melalui perbuatan atau tindakan yang melanggar norma dan adat istiadat dalam suatu masyarakat. Oleh karena itu, tabu dapat dibedakan menjadi dua, yaitu: (1) tabu perbuatan, sebagai contoh: larangan terhadap hubungan sedarah dan (2) tabu bahasa, sebagai contoh: penggunaan kata serapah. Hal tersebut sebagaimana diungkapkan oleh Karjalainen (2002) yang menyatakan bahwa "there are two kinds of taboos that are behavioral, for instance the prohibition against incestuous relation and linguistic, for instance of the use of swearwords". Jay (dalam Rosidin, 2010: 31) menggunakan istilah kutukan untuk menggambarkan tabu bahasa dan membaginya menjadi makian, fitnah, kata-kata kotor, kecabulan, saling mengata-ngatai, agresi verbal, ujaran tabu, hinaan etnis yang bersifat rasial, kekasaran, ketidaksopanan dan skatologi. Dari penjelasan yang diungkapkan oleh Jay, salah satu perwujudan tabu bahasa adalah penggunaan istilah tabu. Istilah tabu hampir dapat ditemui di setiap budaya dan bahasa. Istilah tabu diartikan sebagai kata yang berhubungan dengan seks, religi, fungsi alat tubuh, kelompok etnis, kotoran dan kematian. tabu yang sering kali digunakan dalam percakapan adalah fuck, shit, hell, damn, goddamn, Jesus Christ, ass, oh my god, bitch dan sucks (Jay, 2009).

Terlepas dari sifat istilah tabu yang terlarang, istilah tabu tetap digunakan untuk beberapa alasan. Jay menyatakan bahwa istilah tabu dapat digunakan sebagai alat untuk mengekspresikan emosi (dalam Kusumayani, 2013). Istilah tabu masih dan akan terus digunakan karena dirasa mampu mengekspresikan emosi yang tidak dapat 
disampaikan dengan menggunakan bahasa yang sopan. Setiap pakar mempunyai versi mereka sendiri dalam membuat klasifikasi istilah tabu. Salah satunya adalah Jay (2009) mengemukakan klasifikasi jenis istilah tabu secara lebih mendetail yang dibedakan menjadi sembilan jenis istilah tabu, yaitu: (1) sexual references, (2) profane or blasphemous, (3) scatological referents and disgusting objects, (4) animal names, (5) ethnic-racial-gender slurs, (6) insulting references to perceived psychological, physical, or social deviations, (7) ancentral allusion, (8) substrandard vulgar terms, dan (9) offensive slang.

\section{METODOLOGI}

Penelitian ini merupakan sebuah penelitian deskriptif kualitatif dengan desain studi kasus terpancang. Untuk mendapatkan data dari informan, peneliti membagikan kuesioner dan melakukan diskusi kelompok dimana peneliti dapat memperoleh informasi mengenai kualitas terjemahan istilah tabu secara mendalam dari para informan, yang dengan kata lain penelitian ini menggunakan pendekatan etnografi.

Lokasi penelitian ini adalah media berupa film The Wolf of Wall Street yang ber-setting di kota New York dan Leonardo DiCaprio sebagai tokoh utamanya, yaitu Jordan Belford. Partisipan dalam penelitian ini adalah semua tokoh yang berperan film ini, dan peristiwanya berupa tuturan yang mengandung istilah tabu yang diujarkan oleh para tokoh.

Sumber data adalah dokumen, dan informan yang dipilih dengan menggunakan purposive sampling techniques. Dokumen yang digunakan dalam penelitian ini berupa film The Wolf of Wall Street dan dua versi terjemahannya, serta informan yang terdiri native speaker untuk mengecek keabsahan data dan tiga orang rater. Selanjutnya, data penelitian terdiri dari (1) Data yang berupa istilah-istilah tabu dalam naskah film The 
Wolf of Wall Street beserta dua versi terjemahannya, dan (2) hasil dari kuesioner sekaligus focus group discussion terhadap rater mengenai keakuratan dan keberterimaan terjemahan istilah tabu pada dua versi subtitle terjemahan film The Wolf of Wall Street. Teknik pengumpulan data yang digunakan adalah analisis dokumen, kuesioner, dan focus group discussion. Adapun dua jenis kuesioner yang digunakan dalam penelitian ini adalah kuesioner untuk mengukur tingkat tingkat keakuratan dan keberterimaan terjemahan. Berikut ini tabel skala penilaian tingkat keakuratan dan keberterimaan yang diambil dari Nababan dkk (2012):

Tabel 1. Instrumen Penilaian Keakuratan Terjemahan

\begin{tabular}{ccl}
\hline Kategori & Skala & \multicolumn{1}{c}{ Indikator } \\
\hline Akurat & 3 & $\begin{array}{l}\text { Makna kata, frasa, klausa, kalimat atau teks bahasa sumber dialihkan secara } \\
\text { akurat ke dalam bahasa sasaran; sama sekali tidak terjadi distorsi makna }\end{array}$ \\
\hline $\begin{array}{c}\text { Kurang } \\
\text { Akurat }\end{array}$ & 2 & $\begin{array}{l}\text { Sebagian besar makna kata, frasa, klausa, kalimat atau teks bahasa sumber } \\
\text { sudah dialihkan secara akurat ke dalam bahasa sasaran. Namun, masih terdapat } \\
\text { distorsi makna atau terjemahan makna ganda (taksa) atau ada makna yang } \\
\text { dihilangkan, yang menggangu keutuhan pesan }\end{array}$ \\
\hline $\begin{array}{c}\text { Tidak } \\
\text { Akurat }\end{array}$ & 1 & $\begin{array}{l}\text { Makna kata, frasa, klausa, kalimat atau teks bahasa sumber dialihkan secara } \\
\text { tidak akurat ke dalam bahasa sasaran atau dihilangkan. }\end{array}$ \\
\hline
\end{tabular}

Tabel 2. Instrumen Penilaian Keberterimaan Terjemahan

\begin{tabular}{ccl}
\hline Kategori & Skala & \multicolumn{1}{c}{ Indikator } \\
\hline Berterima & 3 & $\begin{array}{l}\text { Terjemahan terasa alamiah; istilah yang digunakan lazim digunakan dan akrab } \\
\text { bagi pembaca; frasa, klausa, kalimat yang digunakan sudah sesuai dengan } \\
\text { kaidah-kaidah bahasa Indonesian }\end{array}$ \\
\hline $\begin{array}{c}\text { Kurang } \\
\text { Berterima }\end{array}$ & 2 & $\begin{array}{l}\text { Pada umumnya terjemahan sudah terasa alamiah; namun ada sedikit masalah } \\
\text { pada diksi atau terjadi sedikit kesalahan gramatikal }\end{array}$ \\
\hline $\begin{array}{c}\text { Tidak } \\
\text { Berterima }\end{array}$ & 1 & $\begin{array}{l}\text { Terjemahan tidak alamiah atau terasa seperti karya terjemahan; istilah yang } \\
\text { digunakan tidak lazim digunakan dan tidak akrab bagi pembaca; frasa, klausa } \\
\text { dan kalimat yang digunakan tidak sesuai dengan kaidah-kaidah bahasa } \\
\text { Indonesia }\end{array}$ \\
\hline
\end{tabular}

\section{Teknik Analisis Data}

Dalam penelitian ini, peneliti menggunakan teknik analisis menurut Spradley (1980).

Teknik ini memiliki keterkaitan antar bagiannya yang bersamaan dengan proses pengumpulan data. Analisis ini meliputi analisis domain, analisis taksonomi, analisis 
komponensial dan juga analisis tema budaya. Tahap analisis data tersebut dapat dilihat pada gambar berikut:

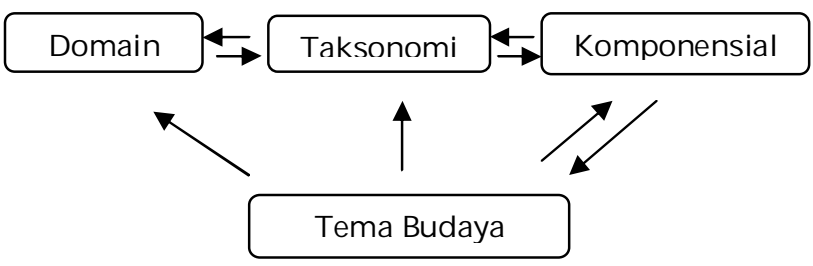

Gambar 1. Skema Tahapan Analisis Data

\section{Analisis Domain}

Dalam tahap ini, data dipilah-pilah dan dimasukkan mana yang termasuk data dan mana yang bukan data. Pada penelitian ini, domain yang diperoleh adalah data berupa istilah tabu yang terdapat dalam film The Wolf of Wall Street beserta dua versi terjemahannya.

\section{Analisis Taksonomi}

Data yang telah didapat kemudian diklasifikasikan berdasarkan variabel-variabel yang sudah ditetapkan. Analisis taksonomi yang pertama dilakukan adalah dengan menganalisis data berdasarkan bentuk satuan gramatikal berdasarkan teori Wijana dan Rohmadi (2006) dan klasifikasi istilah tabu menurut teori Jay Timothy (2009). Kemudian, data yang ada dianalisis teknik penerjemahan yang digunakan berdasarkan teori Molina dan Albir (2002). Analisis taksonomi berikutnya adalah memasukkan kualitas terjemahan dalam segi keakuratan dan keberterimaan.

\section{Analisis Komponensial}

Tahapan ini menunjukkan hubungan antar variabel yang dikaji. Jenis istilah tabu dan teknik penerjemahan istilah tabu yang sudah ditemukan pada analisis taksonomi 
dihubungkan dengan dampak penggunaannya terhadap kualitas terjemahan yang dihasilkan. Analisis komponensial dibagi menjadi dua dikarenakan terdapat dua versi terjemahan yang dikaji dalam penelitian ini.

\section{Analisis Tema Budaya}

Pada penelitian ini, analisis tema budaya menghubungkan teori kajian penerjemahan mengenai teknik penerjemahan dan kualitas terjemahan dengan kajian sosiolinguistik dan teori-teori lain yang mendukung. Analisis tema budaya juga dilakukan dengan membandingkan hasil analisis komponensial terjemahan versi subtitle VCD dan subtitle amatir yang diunduh melalaui situs subscene.com. Dengan analisis tema budaya, temuan penelitian dapat dikaji dengan lebih mendalam sehingga dapat menghasilkan simpulan penelitian yang holistik.

\section{HASIL DAN PEMBAHASAN}

Bagian ini disajikan menjadi dua bagian utama yaitu hasil dan pembahasan. Bagian hasil memaparkan: (1) bentuk dan jenis istilah tabu yang terdapat dalam film the Wolf of Wall Street, (2) teknik penerjemahan yang digunakan dalam menerjemahkan istilah tabu dalam film the Wolf of Wall Street dan dua versi terjemahannya, (3) kualitas terjemahan istilah tabu dalam film the Wolf of Wall Street versi subtitle VCD dan versi subtitle amatir, dipandang dari segi keakuratan dan keberterimaan. Bagian kedua, yakni

pembahasan, memaparkan dampak penggunaan teknik penerjemahan istilah tabu terhadap kualitas terjemahan pada kedua subtitle film the Wolf of Wall Street. Selain itu, hasil penelitian yang ada juga dikorelasikan dengan teori-teori yang bersangkutan. 


\section{Bentuk dan Jenis Istilah Tabu}

Berdasarkan bentuk satuan gramatikalnya, istilah tabu yang ditemukan dalam film the

Wolf of Wall Street adalah istilah tabu berbentuk kata dan frasa.

Dalam penelitian ini, peneliti menemukan sebanyak 98 data istilah tabu yang berbentuk kata. Berdasarkan data yang diperoleh, terdapat 7 jenis istilah tabu yaitu:

Tabel 3. Jenis Istilah Tabu Berbentuk Kata

\begin{tabular}{|c|c|c|}
\hline Jenis & Total & Persentase \\
\hline Offensive Slang & 38 & $38,8 \%$ \\
\hline Sexual Reference & 37 & $37,7 \%$ \\
\hline $\begin{array}{l}\text { Insulting references to perceived psychological, physical, or } \\
\text { social deviations }\end{array}$ & 8 & $8,2 \%$ \\
\hline Scatological referents and disgusting objects & 7 & $7,1 \%$ \\
\hline Profane or Blasphemous & 5 & $5,1 \%$ \\
\hline Animal names & 2 & $2,1 \%$ \\
\hline Ancestral Allusion & 1 & $1 \%$ \\
\hline 98 & & $100 \%$ \\
\hline
\end{tabular}

Sementara itu, istilah tabu berbentuk frasa ditemukan sebanyak 45 data. Dari hasil yang ditemukan, sebagian besar penggunaan istilah tabu merupakan gabungan dari jenis offensive slang dengan jenis istilah tabu yang lain. Berikut tabel jenis istilah tabu yang berbentuk frasa.

Tabel 4. Jenis Istilah Tabu Berbentuk Frasa

\begin{tabular}{|c|c|c|}
\hline Jenis Istilah Tabu & Total & Persentase \\
\hline Sexual Reference & 9 & $20 \%$ \\
\hline Profane or Blasphemous & 3 & $6,7 \%$ \\
\hline Ancestral Allusion & 2 & $4,4 \%$ \\
\hline Offensive dan Scatological referents and disgusting objects & 11 & $24,4 \%$ \\
\hline $\begin{array}{l}\text { Offensive dan Insulting references to perceived psychological, physical, or } \\
\text { social deviations }\end{array}$ & 8 & $17,9 \%$ \\
\hline Offensive dan Sexual Reference & 7 & $15,6 \%$ \\
\hline Offensive dan Animal names & 4 & $8,8 \%$ \\
\hline Offensive dan Profane or Blasphemous & 1 & $2,2 \%$ \\
\hline $100 \%$ & & \\
\hline
\end{tabular}




\section{Teknik Penerjemahan}

1. Temuan Teknik Penerjemahan pada Subtitle versi VCD

Ditemukan bahwa terjemahan istilah tabu dalam film the Wolf of Wall Street versi subtitle VCD menggunakan enam teknik penerjemahan. Berikut presentase temuan masing-masing teknik:

Tabel 5. Temuan Teknik Penerjemahan Pada Subtitle Versi VCD

\begin{tabular}{lcc}
\hline $\begin{array}{c}\text { Teknik } \\
\text { Penerjemahan }\end{array}$ & $\begin{array}{c}\text { Frekuensi } \\
\text { Penggunaan }\end{array}$ & Persentase \\
\hline Padanan Lazim & 80 & $55,95 \%$ \\
\hline Reduksi & 50 & $34,97 \%$ \\
\hline Amplifikasi & 6 & $4,20 \%$ \\
\hline Literal & 3 & $2,09 \%$ \\
\hline Peminjaman & 3 & $2,09 \%$ \\
\hline Generelisasi & 1 & $0,7 \%$ \\
\hline$\sum$ & $\mathbf{1 4 3}$ & $\mathbf{1 0 0 \%}$ \\
\hline
\end{tabular}

\section{Temuan Teknik Penerjemahan Istilah Tabu pada Subtitle Versi Amatir}

Jika dibandingkan dengan terjemahan versi subtitle VCD, terjemahan istilah tabu versi subtitle amatir tidak mempunyai perbedaan jauh dalam penggunaan teknik penerjemahan. Akan tetapi, teknik kuplet muncul dalam hasil analisis teknik penerjemahan pada subtitle amatir.

Tabel 6 Varian Teknik Penerjemahan yang Ditemukan dalam Subtitle Versi Amatir

\begin{tabular}{lll}
\hline $\begin{array}{l}\text { Teknik } \\
\text { Penerjemahan }\end{array}$ & Jumlah & Persentase \\
\hline Tunggal & 142 & $99,30 \%$ \\
\hline Kuplet & 1 & $0,70 \%$ \\
\hline$\sum$ & $\mathbf{1 4 3}$ & $\mathbf{1 0 0 \%}$ \\
\hline
\end{tabular}

Dalam teknik tunggal, terdapat tujuh teknik penerjemahan yang digunakan, yaitu: reduksi, padanan lazim, amplifikasi, generalsisasi, literal, peminjaman, dan kompensasi. Adapun satu teknik kuplet yaitu amplifikasi dan reduksi Tabel dibawah ini 
menunjukkan frekuensi penggunaan masing-masing teknik penerjemahan yang ditemukan:

Tabel 11. Temuan Varian Tunggal Teknik Penerjemahan pada Subtitle Amatir

\begin{tabular}{lcc}
\hline $\begin{array}{c}\text { Teknik } \\
\text { Penerjemahan }\end{array}$ & $\begin{array}{c}\text { Frekuensi } \\
\text { Penggunaan }\end{array}$ & Persentase \\
\hline Padanan Lazim & 66 & $46,48 \%$ \\
\hline Reduksi & 62 & $43,66 \%$ \\
\hline Amplifikasi & 5 & $3,53 \%$ \\
\hline Peminjaman & 3 & $2,11 \%$ \\
\hline Generalisasi & 3 & $2,11 \%$ \\
\hline Literal & 2 & $1,41 \%$ \\
\hline Kompensasi & 1 & $0,7 \%$ \\
\hline \multicolumn{1}{c}{$\sum$} & $\mathbf{1 4 2}$ & $\mathbf{1 0 0 \%}$ \\
\hline
\end{tabular}

\section{Kualitas Terjemahan Istilah Tabu}

\section{Kualitas Terjemahan Istilah Tabu versi VCD}

a. Keakuratan

Pada terjemahan istilah tabu versi VCD, peneliti menemukan tiga kategori keakuratan, yaitu: terjemahan akurat sebanyak 83 data $(58,04 \%)$, terjemahan kurang akurat sebanyak 46 data (32,17\%), dan terjemahan tidak akurat sebanyak 14 data $(9,79 \%)$.

\section{b. Keberterimaan}

Keberterimaan berkaitan dengan kesesuaian terjemahan terhadap bahasa dan norma budaya bahasa sasaran. Pada terjemahan istilah tabu versi VCD, terdapat 3 temuan yang berkaitan dengan keberterimaan yaitu: terjemahan berterima sebanyak 140 data $(97,91 \%)$, terjemahan kurang berterima 2 data $(1,39 \%)$ dan 1 data $(0,7 \%)$ yang tidak berterima. 
2. Kualitas Terjemahan Istilah Tabu versi Amatir

a. Keakuratan

Berdasarkan penilaian kualitas keakuratan terjemahan, terjemahan istilah tabu pada subtitle amatir menghasilkan tiga kategori, yaitu terjemahan akurat 69 data $(48,25 \%)$, kurang akurat 46 data $(32,17 \%)$ dan tidak akurat 28 data $(19,58 \%)$.

b. Keberterimaan

Pada terjemahan istilah tabu versi subtitle amatir, terdapat 3 temuan yang berkaitan dengan keberterimaan yaitu: terjemahan berterima sebanyak 134 data $(93,71 \%)$, terjemahan kurang berterima 8 data $(5,59 \%)$ dan 1 data $(0,7 \%)$ yang tidak berterima.

Perbandingan Teknik Penerjemahan yang Digunakan untuk Menerjemahkan Istilah Tabu pada Subtitle Versi VCD dan Subtitle Amatir.

Jika dilihat dari frekuensi penggunaan masing-masing teknik penerjemahan, maka teknik padanan lazim dan reduksi mendominasi terjemahan versi VCD maupun amatir. Istilah tabu yang ditemukan dalam film the Wolf of Wall Street merupakan istilah yang mayoritas digunakan sebagai kata umpatan untuk mengekspresikan sikap emosional penutur yang tidak dapat diterjemahkan secara kata demi kata. Dalam menerjemahkan istilah yang berupa ekspresi-ekspresi tersebut, penerjemah membutuhkan padanan dengan makna yang sama dan lazim digunakan dalam budaya bahasa sasaran. Meskipun teknik padanan lazim banyak digunakan, beberapa hasil terjemahan pada data yang sama menghasilkan terjemahan yang berbeda, misalnya Piece of shit! diterjemahkan menjadi Bajingan! pada versi VCD dan Keparat! pada versi amatir. Perbedaan tersebut didasari pemilihan diksi yang berbeda antara penerjemah satu dan penerjemah lain. Selain teknik tersebut, teknik reduksi juga banyak diterapkan. Akan tetapi, sebagian besar data yang menggunakan teknik ini menerapkan 
penghilangan istilah tabu yang digunakan berupa intensifier yang memodifikasi kata benda, kata kerja maupun kata sifat. Sebagai contoh: You're not fucking taking my fucking kids! diterjemahkan menjadi Kau tidak bisa membawa anak-anakku! (versi VCD) dan Kau takkan bisa membawa anak-anakku! (versi amatir). Penghilangan istilah tersebut dipakai untuk memapatkan pesan dan juga mempertimbangkan kesediaan ruang dan waktu kemunculan. Namun demikian, teknik reduksi berdampak pada kualitas terjemahan karena menjadikan terjemahan kehilangan nilai emotif yang berbeda.

Diurutan selanjutnya pada terjemahan versi VCD maupun amatir, ditempati oleh teknik amplifikasi. Berdasarkan temuan dalam penelitian ini, teknik amplifikasi digunakan untuk mengeksplisitkan informasi pada bahasa sasaran. Sebagai contoh istilah fuck diterjemahkan menjadi mengacaukan. Fuck biasanya mengacu pada aktivitas seksual tetapi tidak selamanya istilah fuck yang menjadi kata kerja yang selalu dihubungkan dengan aktivitas seksual. Istilah tabu fuck dieksplisitkan dengan maksud untuk dapat menjelaskan makna yang tersembunyi agar pembaca sasaran (penonton) dapat memahami maksud dari istilah tersebut.

Teknik selanjutnya yang berada di posisi keempat adalah teknik literal. Dalam kaitan dengan istilah tabu, pada dasarnya teknik literal juga dapat muncul ketika peneliti menganalisis teknik penerjemahan. Berdasarkan temuan pada subbab sebelumnya, teknik ini digunakan ketika penerjemah menerjemahkan istilah tabu secara harfiah tanpa mempertimbangkan konteks yang ada.

Sementara itu dalam terjemahan versi amatir, teknik peminjaman diurutan keempat. Disisi lain, teknik peminjaman berada pada urutan kelima dalam terjemahan versi VCD. Dalam terjemahan istilah tabu versi VCD dan amatir, teknik peminjaman digunakan untuk menerjemahkan istilah tabu yang berkaitan dengan wujud benda 
aslinya, misalnya istilah penis diterjemahkan menjadi penis dalam subtitle VCD maupun amatir.

Pada terjemahan versi VCD yang paling sedikit digunakan adalah teknik generalisasi yaitu sebanyak 1 kali kemunculan. Teknik tersebut digunakan untuk menerjemahkan istilah dick menjadi kemaluan. Berbeda dengan versi VCD, teknik generalisasi ditemukan sebanyak 3 kali diurutan kelima dan literal sebanyak 1 kali diurutan keenam. Jika terjemahan versi VCD hanya menerapkan 6 jenis teknik penerjemahan, terjemahan versi amatir masih mempunyai 1 teknik penerjemahan lagi, yaitu teknik kompensasi.

\section{Perbandingan Kualitas Terjemahan Istilah Tabu pada Subtitle VCD dan Subtitle}

\section{Amatir}

Berdasarkan hasil temuan, terjemahan istilah tabu yang dihasilkan pada subtitle versi VCD maupun subtitle amatir memiliki kualitas relatif cukup baik. Jika dibandingkan, subtitle versi VCD memiliki tingkat keakuratan terjemahan istilah tabu lebih tinggi yakni sebanyak $58,04 \%$ sedangkan tingkat keakuratan terjemahan istilah tabu pada subtitle amatir sebanyak 48,25\%.

Dari hasil perbandingan di atas, dapat disimpulkan bahwa terjemahan istilah tabu dalam subtitle versi VCD memiliki tingkat keakuratan yang lebih tinggi. Dengan kata lain, penerjemah mampu menyajikan terjemahan yang sepadan dengan pesan yang terdapat dalam bahasa sumber.

Selanjutnya berdasarkan keberterimahan terjemahan, subtitle VCD juga memiliki tingkat keberterimaan terjemahan istilah tabu yang lebih tinggi sebesar 97,91\%. Sementara itu, terjemahan istilah tabu dalam versi amatir memiliki tingkat 
keberterimaan sebesar $93,71 \%$. Terjemahan istilah tabu yang dihasilkan oleh masingmasing subtitle menunjukkan bahwa sebagian besar, yakni lebih dari 90\%, terjemahan tergolong dalam terjemahan berterima. Pada umumnya, terjemahan istilah tabu pada dua versi subtitle masih terkesan kasar atau tidak sopan dalam bahasa sasaran. Meskipun demikian, istilah tabu tersebut masih dapat dikatakan berterima secara linguistik dan budaya. Istilah tabu yang terdapat dalam film the Wolf of Wall Street digunakan sebagai sarana untuk mengekspresikan emosi berdasarkan konteks situasi tanpa melanggar norma sosial.

\section{Dampak Teknik Penerjemahan terhadap Keakuratan dan Keberterimaan Terjemahan (Subtitle VCD dan Amatir)}

Pada subtitle VCD, teknik padanan lazim memiliki andil besar dalam menghasilkan terjemahan yang akurat dan berterima pada setiap jenis istilah tabu. Hal ini dilatarbelakangi oleh banyaknya istilah tabu yang dicari padanannya dalam bahasa sasaran. Penerjemah menerjemahkan istilah tabu dengan menggunakan istilah yang sudah lazim digunakan sehari-hari maupun ada dalam kamus. Contoh: Jesus Christ! diterjemahkan menjadi Astaga! Istilah tersebut digunakan sebagai ekspresi keterkejutan penutur. Beberapa teknik lainnya; seperti: generalisasi, literal, peminjaman dan amplifikasi juga mampu menghasilkan terjemahan yang akurat dan berterima meskipun sebagian kecil penerapannya kurang tepat sehingga menghasilkan terjemahan yang kurang akurat dan kurang berterima. Senada dengan hal tersebut, teknik reduksi mayoritas digunakan dalam menerjemahkan istilah tabu yang berjenis offensive slang. Akan tetapi, penghilangan tersebut berpotensi menghasilkan terjemahan tidak akurat. Penghilangan justru membuat terjemahan kehilangan nilai emotif yang ingin 
disampaikan dengan menggunakan intensifier sebagai penekanan ekspresi emosional penutur. Akan tetapi, penerapan teknik reduksi tidak menggangu tingkat keberterimaan terjemahan. Sebagian besar istilah tabu yang diterjemahkan menggunakan teknik reduksi menghasilkan terjemahan dengan tingkat keberterimaan tinggi.

Hal yang serupa dengan temuan subtitle VCD, tampak pula dalam subtitle amatir. Pengaplikasian teknik padanan lazim menghasilkan terjemahan istilah tabu yang akurat dan berterima sedangkan teknik reduksi menghasilkan sebagian besar terjemahan kurang bahkan tidak akurat tetapi berterima. Sebagai contoh: Asshole, get out of there! diterjemahkan menjadi Keluar! Istilah asshole yang digunakan untuk

melabeli seseorang yang menjengkelkan dihilangkan dalam bahasa sasaran. Penghilangan tersebut membuat terjemahan masuk ke dalam kategori tidak akurat. Selain kedua teknik tersebut, ditemukan juga teknik generalisasi, amplifikasi, peminjaman, literal, kompensasi dan 1 teknik kuplet yaitu amplifikasi dan reduksi. Keenam teknik tersebut masing-masing menghasilkan terjemahan yang akurat dan kurang akurat tetapi berterima.

\section{Hubungan Makna, Budaya dengan Penggunaan Istilah Tabu dalam Penerjemahan}

Penelitian ini mengangkat film the Wolf of Wall Street sebagai sumber data. Film ini menyoroti kehidupan seorang pialang saham yang bernama Jordan Belford dimana dalam kehidupannya dikelilingi orang-orang yang keras sehingga berpengaruh pada tingginya penggunaan istilah tabu. Selain itu, penulis naskah memang sengaja untuk mempertahankan istilah-istilah yang cenderung kasar sebagai gaya bahasa mereka sehari-hari. Hal tersebut sangat bertolak belakang dengan apa yang ada di Indonesia. Media Indonesia sangat jarang menggunakan istilah-istilah tabu dalam gaya bahasa 
mereka. Meskipun demikian, hal tersebut tidak menjadi permasalahan besar dalam penerjemahan apabila seorang penerjemah dapat mengetahui cara untuk mengatasi masalah tersebut.

Istilah tabu yang ditemukan dalam film the Wolf of Wall Street sebagian besar digunakan sebagai kata umpatan yang mengekspresikan kekesalan, keterkejutan, ketidakpedulian, dan sebagainya. Hal tersebut sedapat mungkin juga harus diterjemahkan secara akurat dan berterima dalam bahasa sasaran. Oleh karena itu, penerjemah harus mengakomodir pesan yang terkandung dalam bahasa sumber ke dalam bahasa sasaran dengan mencari padanan yang lazim yang sudah ada di dalam bahasa sasaran dimana memiliki makna yang sama dengan bahasa sumber. Untuk itu, penerjemah bisa menggunakan teknik padanan lazim untuk mencari padanan yang lazim digunakan dalam bahasa sasaran. Dalam kaitannya dengan keberterimaan, budaya Indonesia menganggap istilah-istilah yang digunakan untuk mengumpat tidak berterima karena melanggar norma dan dianggap tabu untuk diucapkan. Meskipun demikian, istilah-istilah tabu yang cenderung kasar yang ditemukan dalam film the Wolf of Wall Street tersebut tetap diterjemahkan dan dianggap berterima dalam budaya bahasa sasaran. Hal tersebut dilatarbelakangi oleh masih berlakunya dan masih akan terus digunakannya istilah tabu karena dianggap mampu menyampaikan kadar emosi yang tidak bisa disampaikan oleh istilah non tabu. Selain itu, keberterimaan suatu istilah dapat dilihat dari konteks situasi dimana ekspresi tersebut digunakan untuk mengungkapkan kemarahan, kekesalan, kekecewaan, dan sebagainya. Oleh karena itu, istilah-istilah seperti bajingan, keparat, pelacur, dll merupakan umpatan lazim yang biasa digunakan dalam budaya bahasa Indonesia. Meskipun demikian, istilah-istilah 
tersebut sebaiknya tidak diucapkan karena membawa efek negatif yang dapat menyinggung ataupun menyakitkan hati mitra tutur.

\section{SIMPULAN DAN SARAN}

\section{Simpulan}

Dari hasil penelitian di atas, terdapat dua satuan gramatikal istilah tabu, yaitu kata dan frasa. Jenis istilah tabu yang paling banyak ditemukan adalah sexual references dan offensive slang. Dalam kedua subtitle, ditemukan bahwa teknik padanan lazim merupakan teknik yang paling mendominasi dan memiliki andil positif terhadap tingkat keakuratan dan keberterimaan terjemahan istilah tabu. Sedangkan, teknik reduksi dan teknik lain memberi pengaruh yang negatif terhadap kualitas terjemahan istilah tabu. Terjemahan yang dihasilkan dari pengaplikasian teknik reduksi dan teknik lainnya menghasilkan terjemahan dengan tingkat keakuratan yang sedang hingga rendah tetapi terjemahan berterima.

\section{Saran}

Pada dasarnya, istilah tabu cenderung merupakan istilah yang kasar dan bertentangan dengan budaya tetapi penghilangan bukan lah satu-satunya strategi yang tepat untuk menerjemahkannya. Penerjemah diperbolehkan untuk menerjemahkan istilah tersebut dengan istilah yang lazim digunakan dalam budaya bahasa sasaran. Selain itu, penerjemah juga dapat memperhalusnya dengan istilah lainnya yang mempunyai makna yang sepadan dengan istilah dalam bahasa sumber. Dengan demikian, penerjemah dapat

menyajikan suatu terjemahan yang akurat dari segi pesan dan juga berterima dalam budaya bahasa sasaran. 
Peneliti juga menyadari bahwa penelitian ini hanya mengkaji aspek minor yang terfokus pada perbandingan teknik penerjemahan istilah tabu dalam film the Wolf of Wall Street dan dua versi terjemahannya serta dampaknya pada kualitas terjemahan. Oleh karena itu, peneliti lain dapat mengkaji aspek lainnya dengan menggunakan hasil penelitian ini sebagai awal untuk melakukan penelitian dengan cakupan yang lebih luas dan bermanfaat.

\section{DAFTAR PUSTAKA}

Alavi Younes Sayed et al. (2012). Translation of Taboos from English into Persian: A Skopos-Based Study. Iran: Islamic Azad University.

Jay, T. (2009). The Utility and Ubiquity of Taboo Words. Perspectives on Psychological Science , 4(2), 153-161

Kusumayani, Arum. (2013). Analisis Teknik Penerjemahan Istilah Tabu dalam film berjudul "The Hurt Locker" dan Pengaruhnya terhadap Kualitas Terjemahan. Thesis. Pascasarjana UNS.

Larson, Mildred. (1998). Meaning Based Translation: A Guide to Cross Language. Lanham: University Press of America.

Molina, Lucia \& A. Hutardo Albir. (2002). Translation Techniques Revisited: A Dinamic and Funtionalist Approach. In Meta, XLVII,4,2002.

Nababan, M.R. (2003). Teori Menerjemah Bahasa Inggris. Yogyakarta: Pustaka Pelajar.

Nababan, Nuraeni \& Sumardiono. (2012). Pengembangan Model Penelitian Kualitas Terjemahan. Dalam Jurnal Kajian Linguistik dan Sastra, Vol.24, No.1., Juni 2012, 39-57.

Newmark, Peter. (1988). A Textbook of Translation. Oxford: Pergamon Press.

Nida, E.A. \& Taber, C.R. (1982). The Theory and Practice of Translation. Leiden: EJ Brill.

Rosidin, O. (2010). Kajian Bentuk, Kategori dan Sumber Makian, serta Alasan Penggunaan Makian oleh Mahasiswa. Jakarta: UI.

Sarangin, E. (1968). The Anatomy of Dirty Words. New York: The Polyglot Press. 
Spradley, James P. (1980). Participant Observation. New York: Holt, Rinehart and Winston.

Wijana \& Rohmadi. (2006). Sosiolinguistik Kajian Teori dan Analisis. Yogyakarta: Pustaka Pelajar. 